\title{
Editorial: Shifting to Super Principals
}

New Zealand Journal of Teachers' Work, Volume 12, Issue 2, 96-98, 2015

\section{NESTA DEVINE \& LEON BENADE Co-Editors}

The mid-1980s was a period of tumultuous change in New Zealand socio-political and economic life, and education was central to those changes, encapsulated in the well-known 'Tomorrow's Schools' reform, the 1989 Education Act, and subsequent amendments to the Education Act. Many of these changes were hotly debated, contested and challenged (Codd, 2005; Gordon, 1997). One of the most significant changes was the apparent devolution of control for governance and oversight of school management to elected Boards of Trustees.

The 'new' form of Boards of Trustees, which replaced boards of governors in Secondary Schools and School Committees in primary schools, reflected the compromises reached between those in the Picot committee who valued 'community' input, and those who valued efficiency. The tension was between those for whom 'community' meant families, parents, and neighbours, and Treasury and State Services officials, for whom 'community' meant, as it does in Public Choice Theory, the actions of individuals who seek temporary collaborations for the purposes of their own self interest. Clearly, this interpretation had the support of the capitalist middle class professionals. Successful Treasury appeals to 'provider capture' ensured that teachers were excluded from any substantive role on Boards, though principals found themselves in the fraught position of being a Board member with loyalties to the Board not the school, and delivering explanations and suggestions to other Trustees who may have little idea of the exigencies and possibilities of education.

Over the following decades, 'community' participation and control at the local level, embodied in the Boards of Trustees, has embedded itself into the very fabric of New Zealand life. The periodic flush of activity that is the election of trustees to school boards is gaining momentum across the length and breadth of the land, even as we write.

Whereas there may have been misgivings in the education community in the early 1990s about the shifts brought about by reform, including governance by Boards, and the evolution of the principal as the 'Chief executive Officer' of the Board, this arrangement has now too become embedded in New Zealand education. As matters currently stand, many principals and Boards consider their roles to be sacrosanct, and both principals and Boards guard the 'independence' of self-management that the Education Act of 1989 permitted.

As an example, we allude to the previous issue of this journal, in which we featured some opinion pieces concerning the development of flexible or 'innovative' learning environments. Those contributions were written partly in the context of negative media reporting that featured the opposition of some principals to the idea of the Ministry of Education foisting these new builds onto 
school communities (Johnston, 2015; Morris, 2015; Walters, 2015). Here were reports of principals flexing their muscles.

The national education context is now facing some changes, the likes of which have not been seen since 1989. New government educational initiatives include Investing in Educational Success (IES), Communities of Learning (COL), and the review of the Education Act. There appears to be the prospect, highlighted by one of our contributors this issue (Smardon, Charteris \& Nelson), of the role of the principal evolving yet again, this time to becoming similar to the 'Superintendent' seen in American schools.

The IES "is intended to enable the most effective teachers and principals to share their knowledge and expertise across multiple schools, to everyone's benefit." (Ministry of Education, 2016. "How IES will work"). The COL "are the 'engine room' of IES. Groups of schools and kura will come together into groups of around 10 schools which will represent the 'pathway' for students from primary to secondary school." (2016. "Communities of Learning"). Among the policy intentions of the IES is the creation of a 'super principal' and a 'change principal'. The former will "support all principals and teachers in a Community of Learning to meet shared achievement challenges, and will use the principal's project leadership abilities to harness the best skills from across the Community" (2016. "Working across a Community of Learning: Providing leadership"). The latter will be specially selected principals who will "transform struggling schools.) (2016. "Recruiting highly effective principals to schools with challenges").

In the context of possible revisions to the Education Act, coupled with the IES/COL initiatives, the Ministry of Education is leaving no stone unturned, and has raised the question of whether principals should continue to be full members of Boards of Trustees. This suggestion has been met by consternation among principals, with the office of the National President of the New Zealand Principals' Federation being inundated by emails from members, leading him to lobby the Secretary of Education on behalf of principals who demand the status quo in respect of the principal's role on Boards of Trustees 1

Arguably, the evolution of the roles of 'super principal' and 'change principal' have multiple ramifications, including, especially for the former, appointment, lines of reporting and appraisal. These are early days yet, but as the first few COS are being instituted as we write, and as the Education Act review will no doubt lead to the tabling in Parliament of suggested amendments in the not distant future, we anticipate significant educational policy change in the next year.

\footnotetext{
${ }^{1}$ Personal correspondence with lain Taylor, National President of the NZPF, April 30, 2016.
} 


\section{REFERENCES}

Codd, J. (2005). Teachers as 'managed professionals' in the global education industry: the New Zealand experience. Educational Review, 57(2), 193-206.

Gordon, L. (1997). 'Tomorrow's Schools' today: school choice and the education quasi-market. In M. Olssen \& K. Morris Matthews (Eds.), Education policy in New Zealand: the 1990s and beyond Palmerston North: Dunmore Press.

Johnston, K. (2015, May 11). Grammar eschews beanbag lessons in \$6m classroom upgrade. New Zealand Herald. Retrieved May 1, 2016 from http://www.nzherald.co.nz/nz/news/article.cfm?c id=1\&objectid=11446451

Ministry of Education. (2016). Investing in Educational Success. Retrieved April 30, 2016 from http://www.education.govt.nz/ministry-ofeducation/specific-initiatives/investing-in-educational-success/

Morris, J. (2015, May 15). Grammar wise to steer clear of the 'one size fits all' classrooms. New Zealand Herald. Retrieved May 1, 2016 from http://www.nzherald.co.nz/nz/news/article.cfm?c id=1\&objectid=11448816

Walters, L. (2015, October, 18). Top schools give multi-million dollar classrooms a fail grade. Sunday Star Times. Retrieved May 1, 2016 from http://www.stuff.co.nz/national/education/73042309/Top-schools-give-multi$\underline{\text { million-dollar-classrooms-a-fail-grade }}$ 